\title{
Epidemiologic aspects of male infertility
}

\section{Arunadevi Velu*, Geetha Prasad}

Department of Obstetrics and Gynecology, Karpaga Vinayaga Institute of Medical Science and Research Centre, Madhuranthagam, Tamil Nadu, India

Received: 04 July 2017

Accepted: 20 July 2017

\section{*Correspondence:}

Dr. Arunadevi Velu,

E-mail: draruna83@gmail.com

Copyright: (c) the author(s), publisher and licensee Medip Academy. This is an open-access article distributed under the terms of the Creative Commons Attribution Non-Commercial License, which permits unrestricted non-commercial use, distribution, and reproduction in any medium, provided the original work is properly cited.

\begin{abstract}
Background: Infertility affects $10-15 \%$ of couples worldwide with rates steadily increasing in the Industrialized world, in part due to the deterioration of male reproductive health.

Methods: This study was performed in an attempt to clarify the associated factors that might play a role in group of Indian infertile men. This study was a cross - sectional descriptive study conducted in Karpaga Vinayaga Institute of Medical Sciences. The information was obtained from the men who had attended the clinic from January 2016January 2017. The factors that were studied in this research are the demographic characteristics, alcohol consumption, smoking, exposure to heavy metals, obesity, stress and history of surgery.

Results: In $31.6 \%$ of couples, the cause of infertility was pure male factor and in $20.4 \%$ of them the problem was related to male and female factor both. The most important associated factors for male factor included history of varicocele operation (24\%), alcohol consumption (18\%) and cigarette smoking (16\%).

Conclusions: Male factors play a significant role in up to 50 percent of infertility cases, stressing the need for a logical, stepwise approach to the evaluation of the male partner.
\end{abstract}

Keywords: Alcohol consumption, Male infertility, Varicocele

\section{INTRODUCTION}

Infertility is a global problem, affecting approximately 15 percent of couples of reproductive age..$^{1}$ It is estimated that globally, 60-80 million couples suffer from infertility every year, of which approximately 15-20 million are in India alone. ${ }^{2}$ Male factor contributes to infertility as much as $51.2 \%$ according to a large World Health Organisation(WHO) study of more than 8500 couples. ${ }^{3}$

Considerable controversy exists over the concept of male climateric or "andropause". ${ }^{4}$ Growing evidence indicates that some ageing men have reduced production of testosterone associated with decreased libido, impotence, decreased growth of body hair, decreased muscle mass, fatigue, increased risk of myocardial infarction and decreased muscle mass in conjuction with osteoporosis. It is well established that smoking has detrimental effects on spermatogenesis as it has correlated with significantly lower sperm counts, decreased motility and impaired morphology. ${ }^{5-8}$ Impotence, testicular atrophy and loss of sexual interest are associated with alcoholism and reduced FSH, LH and testosterone levels have been found as a result of excessive drinking. ${ }^{9}$

The incidence of varicocele is about $35 \%$ in men with primary infertility and up to $80 \%$ in men with secondary infertility. ${ }^{10}$ Varicocele increases scrotal temperature by causing venous stasis which leads to damage to spermatogenesis and progressive deterioration of sperm parameters. Other mechanisms like toxin reflux is also suggested in varicocele-induced testicular damage. ${ }^{11}$ 
Acute illness can cause hypothalamic dysfunction and chronic illnesses can cause hypothalamic or testicular dysfunctions. ${ }^{12}$ Genital tract infections are the major causes of antisperm antibody formation in men. ${ }^{13}$ More than four decades ago, Stamey et al, showed that the first $10 \mathrm{ml}$ of urine of normal volunteer men contain 50-3000 colonies/ml of diphtheroids, staphylococcus and streptococcus. ${ }^{14}$ Subsequent studies showed that Mycoplasma and Chlamydia are often isolated in the first void urine. ${ }^{15,16}$ Obstruction of male genital tract ductal system may account for around 15 percent of all infertility in the male. ${ }^{17}$

A label of infertile in the male has been associated with a significant decrease in health-related quality of life and sexual function which should be discussed during the evaluation process and gives us further impeties to treat these men expeditiously. ${ }^{18,19}$ Therefore, we decided to investigate the epidemiology of male infertility in Karpaga Vinayaya Institute of Medical Sciences, a referral centre for infertility in India.

\section{METHODS}

This study was a cross-sectional, descriptive study that was performed at Karpaga Vinayaga Institute of Medical Science in 1000 infertile men from January 2016 to January 2017. The purpose of this study was to determine the frequency of male infertility and its associated factors. Variables examined included age, smoking, alcohol consumption, heavy metals exposure, history of varicocele operation, stress, obesity and undescended testis. The statistical tests including frequency tables, graphs, mean, median and standard deviation were used. Since the design of the study was cross-sectional, descriptive, we did not use any statistical analysis. This study was approved by ethical committee.

\section{RESULTS}

$\mathrm{T}$ In a total number of 520 patients $(52 \%)$ with male infertility, the cause of infertility was pure male factor in 316 couples $(31.6 \%)$ and male - female both in 204 $(20.4 \%)$. The age range was between $20-50$ years. The infertility period was less than 5 years in 210 patients (40\%), 5-9 years in 166 patients $(32 \%)$ and $>10$ years in 144 patients $(28 \%)$.

The demographic characteristics of the patients are shown in Table 1. Based on the results of semen analysis, $35(6 \%)$ patients showed azoospermia, 26 patients $(5 \%)$ had only abnormal sperm morphology, 91(17.5\%) only impaired motility and $117(22.5 \%)$ of subjects had only oligospermia but 261 (49\%) patients had two or more abnormal parameters. The results of the study about associated factors are shown in Table 2. The most common factor was history of varicocele operation in 126 (24\%) patients, followed by alcohol consumption in 94 (18\%) patients in their past history.
Table 1: Demographic characteristics of study.

\begin{tabular}{|l|l|}
\hline Variables & Frequency $(\%)$ \\
\hline Age (year) & \\
\hline $20-40$ & $205(39.4 \%)$ \\
\hline $41-50$ & $41-50$ \\
\hline Education & $236(45 \%)$ \\
\hline Diploma and above & $102(20 \%)$ \\
\hline High school & $128(25 \%)$ \\
\hline Primary and secondary & \\
\hline Occupation & $272(52 \%)$ \\
\hline Employee & $136(26 \%)$ \\
\hline Labourer & $112(22 \%)$ \\
\hline Others & \\
\hline Duration of infertility & $210(40 \%)$ \\
\hline$<5$ years & $166(32 \%)$ \\
\hline 5-10 years & $144(28 \%)$ \\
\hline$>10$ years & \\
\hline
\end{tabular}

Table 2: Associated factors identified in study group.

\begin{tabular}{|ll|}
\hline Variables & Frequency (\%) \\
\hline Operation & \\
\hline Varicocele & $126(24 \%)$ \\
\hline Hernia & $42(8 \%)$ \\
\hline Orchiopexy & $26(5 \%)$ \\
\hline Alcohol consumption & $94(18 \%)$ \\
\hline Cigarette smoking & $82(16 \%)$ \\
\hline Undescended testis & $32(6 \%)$ \\
\hline Obesity & $22(4 \%)$ \\
\hline Heavy metals exposure & $13(3 \%)$ \\
\hline Stress & $16(3 \%)$ \\
\hline Idiopathic & $67(13 \%)$ \\
\hline
\end{tabular}

\section{DISCUSSION}

Obesity causes increased scrotal temperature by increasing the proximity of thighs to scrotum and excessive fat accumulation increases peripheral conversion of testosterone to estrogen which negatively affects spermatogenesis and sperm quality. ${ }^{20}$

Several studies reported that heavy metal toxicity in men impaired spermatogenesis and decreased sperm counts. ${ }^{21-}$ 24 Inorganic lead can disturb the pro-oxidant and antioxidant balance and cause oxidative stress. ${ }^{22}$ Antibiotics and chemotherapy can damage germinal epithelium. ${ }^{25}$ Many anti-bacterial drugs (eg. Tetracycline derivatives, sulfa drugs) impair spermatogenesis and chronic use can lead to infertility.

Eskiocak was able to link intervals of psychological stress with a reduction in sperm quality mediated by an increase in seminal plasma ROS generated and a reduction in antioxidant protection. It has also been said that stress can lead to increased levels of glucocorticoids and decreased levels of testosterone. ${ }^{28}$ Various epidemiological studies proposed that cell phone 
usage might cause decrease in sperm count and other sperm parameters. ${ }^{29,30}$ A study of Friedman et al revealed that cell phone radiation could lead to generation of ROS. ${ }^{31}$ As societies increasingly introduce new chemical and potentially toxic substance into daily life, adverse effects may be amplified from one generation to the next. This is an issue that both developed and developing countries face. These environmental factors can disrupt endocrine functions eventually leading to fertility problems.

\section{CONCLUSION}

The increase in defective spermatogenesis, testicular cancer, cryptorchidism, and numerous other male fertility issues over the course of the past few decades is a great cause of concern and has prompted the investigation of environmental and lifestyle factors that may be responsible. While assisted reproductive techniques have advanced in recent years and allows couples to bypass semen quality issues by directly injecting sperm into an egg, this only treats the symptom and not the issue itself. By eliminating or reducing certain environmental or lifestyle factors, male fertility as a whole may increase.

\section{ACKNOWLEDGMENTS}

Author acknowledges the enormous help received from the scholars whose articles have been cited and incorporated in references.

\section{Funding: No funding sources}

Conflict of interest: None declared

Ethical approval: The study was approved by the Institutional Ethics Committee

\section{REFERENCES}

1. De Krister DM. Male infertility. Lancet. 1997;349:787-9.

2. World Health Organization, the World Health Report Geneva ; WHO;1996.

3. World Health Organization. Towards more objectivity in diagnosis and management of male infertility. Results of a WHO multicenter study. Int J Androl. 1987;(suppl 7):1-35.

4. Tenover JS. Androgen administration to aging men. Endocrinol Metab Clin North Am. 1994;23:877-92.

5. Swartz CM, Young MA, Low serum testosterone and myocardial infarction in Geriatric male inpatients. J Am Geriatric Soc. 1987;35:39-44.

6. Kunzle R. Mueller MD, Hanggi W, Birkhauser MH, Drescher H, Bersinger NA. Semen quality of male smokers and nonsmokers in infertility couples. Fertility and sterility. 2003;79 (2):287-91.

7. Saleh RA, Agarwal A, Sharma RK, Nelson Dr, Thomas AJ Jr. Effect of cigarette smoking on levels of seminal oxidative stress in infertile men: a prospective study. Fertil Steril. 2002;78 (3):491-9.
8. Vine MF, Tse CK, Hu P, Truong KY. Cigarette smoking and semen quality. Fertil Steril. 1996;65(4):835-42.

9. Boyden TW, Pamenter RW. Effects of ethanol on the male hypothalamic-pituitary gonadal axis. Endocrine Rev. 1983;4(4):389-95.

10. Witt MA, Lipshultz LI. Varicocele: a progressive or static lesion? Urology. 1993;42(5):541-3.

11. Filhow DW, Torress MA. Spermatic Cord torsion, reactive oxygen and nitrogenspecies and ischaemia perfusion injury. Mol Aspects Med. 2004;25:199210.

12. Baker HW. Reproductive effects of nontesticular illness. Endocrinol Metab Clin North Am. 1998;27(4):831-50.

13. Turek PJ. Immuno pathology and Infertility. In; Lispshultz LI, Howards SS (Eds). Infertility in the male, $3^{\text {rd }}$ edition. St. Louis, Mo: Mosby year book;1997:305-25.

14. Meares EM, Stamey TA. Bacteriologic Localization in bacterial prostatitis and Urethritis. Invest Urol. 1968;5:492-503.

15. Klousia JW, Madden RL, Fucillo DA et al. The aetiology of nonspecific urethritis in active duty marines. J Urol. 1978;120:67-70.

16. Holmes KK, Handsfield $\mathrm{HH}$, Wang SP, et al. Etiology of nongonocoical urethritis. N Eng Med. 1975; 292; 1995-1205.

17. Jequier AM. Obstructive azoospeprmia: a study of 102 patients. Clinical Repord Fertil. 1986;3:21-36.

18. Shindel AW, Nelson CJ, Naughton CK, Ohebshalom M, Mulhall JP. Sexual function and quality of life in the male partner of infertile couple: prevalence and correlates of dysfunction. J Urol. 2008;179(3):1056-9.

19. Van Balen F, Trimbos-Kemper TC. Factors influencing the well-being of long term infertile couples. J Psychosom Obstet Gynecol. 1994;15(3):157-64.

20. Cucadia AN. Obesity in male: potential Impact on reproductive function. J Urol. 1996;156:1643-5.

21. Acharya UR, Acharya S, Mishra M. Lead acetate induced cytotoxicity in male germinal cells of swiss mice. Industrial Health. 2003;41(3):221-4.

22. HSU PC, Cuo YL. Antioxidant Nutrients and lead toxicity. Toxicology. 2000;180(1):33-44.

23. Naha N, Chowdhury AR. Inorganic Lead exposure in battery and paint factory; Effect on human sperm structure and Functional activity. J UCEH. 2006;28(2):157-71.

24. Xu Dx, Shen HM, Zlu QX, Chua L,Wang QN, Chia $\mathrm{SE}$ et al. The associations among semen quality, Oxidative DNA damage in human spermatozoa and concentrations of cadmium, lead and selenium in seminal plasma. Mutation Res. 2003;534(1-2):15563.

25. Shalet SM. Effects of cancer chemotherapy on gonadal function of patients. Cancer Treatment Rev. 1980;7(3):141-52. 
26. Schlegel PN, Chang Ts, Marshall FF. Antibiotics; potential hazards to male fertility. Fertil Steril. 1991;55(2):235-42.

27. O' Marain C, Smethurst P, Dore CJ, Levi AJ. Reversible male infertility due tosulphasalazine: Studies in man and rat. Gut 1984;25(10):1078-84.

28. Eskiocak S, Gozen As, Taskiran A, Kilic As, Eskiocak M, Gulen S. Effect of Psychological stress on the L-arginine- nitric oxide pathway and semen quality. Brazilian J Med Biol Res. 2006;39(5):581-8.

29. Agarwal A, Desai NR, Makker K,Varghese A, Mouradi R, Sabanegh E et al. Effects of radiofrequency electromagnetic waves (RF-EMW) from cellular phones on human ejaculated semen; an in vitro pilot study. Fertil Steril. 2008.

30. Deepinder F, Makker K, Agarwal A. Cell phones and male infertility; dissecting the relationship. Reprod Biomed Online. 2007;15(3):266-70.

31. Friedman J, Kraus S, Hauptman Y, Schiffy, Seger R. Mechanism of short-term ERK activation by electromagnetic fields at Mobile phone frequencies. Biochem J. 2007;405(3):559-68.

Cite this article as: Velu A, Prasad G.

Epidemiologic aspects of male infertility. Int $\mathrm{J}$

Reprod Contracept Obstet Gynecol 2017;6:3362-5. 